\title{
The influence of casein haplotype on morphometric characteristics of fat globules and fatty acid composition of milk in Italian Holstein cows
}

\author{
Annamaria Perna, ${ }^{1}$ Immacolata Intaglietta, Amalia Simonetti, and Emilio Gambacorta \\ School of Agricultural, Forestry, Food and Environmental Sciences, University of Basilicata, Viale dell'Ateneo Lucano 10, Potenza, 85100, Italy
}

\begin{abstract}
The aim of this work was to investigate the effect of casein haplotypes $\left(\alpha_{S 1^{-}}, \beta\right.$-, and $\kappa$-caseins) on morphometric characteristics of fat globules and fatty acid composition of Italian Holstein milk. Casein haplotypes were determined by isoelectric focusing; milk fat globule size was measured by using a fluorescence microscope; and fatty acid profile was determined by gas chromatography. Casein haplotype significantly affected the fat globule size, the percentage incidence of each globule size class on total measured milk fat globules, and fatty acid composition. A higher incidence of smaller milk fat globules was associated with the $B B-A^{2} A^{2}-B B$ genotype $\left(\alpha_{\mathrm{S1}^{-}}, \beta-\right.$, and $\kappa$-casein haplotypes, respectively), whereas small globules were not detected in $B B-A^{2} A^{1}-A A$ milk, but that milk had the highest percentage of large globules. A higher content of monounsaturated fatty acids was associated with the $B B-A^{2} A^{2}-A B$ genotype, whereas higher contents of conjugated linoleic acid and docosahexaenoic acid were detected in $B B-A^{1} A^{1}-A A$ milk. Our results indicate that casein haplotype could affect fat characteristics and, therefore, the nutritional and technological quality of milk.
\end{abstract}

Key words: casein haplotype, milk fat globule size, fatty acid profile, Italian Holstein cows

\section{INTRODUCTION}

The milk proteins of ruminants have a complex genetic variability. In particular, $\alpha_{\mathrm{S1}^{-}}, \beta-$, and $\mathrm{k}-\mathrm{CN}$ have many genetic variants that can result from SNP or from nucleotide deletions or insertions, which affect, at the phenotypic level, both milk composition and cheesemaking properties (Di Stasio and Mariani, 2000; Caroli et al., 2009). Casein genes were the first to be identified and sequenced entirely. Close linkage among the caseins was detected through physical mapping techniques, showing that $\alpha_{\mathrm{S}^{-}} \mathrm{CN}, \beta-\mathrm{CN}, \alpha_{\mathrm{S}^{-}} \mathrm{CN}$, and к-CN are coded by 4 genes (CSNS1, CSN2, CSN1S2,

Received September 14, 2015.

Accepted December 22, 2015.

${ }^{1}$ Corresponding author: anna.perna@unibas.it and $C S N$, respectively) tightly linked in a $250-\mathrm{kb}$ cluster on chromosome 6 (Martin et al., 2002). Many authors (Ojala et al., 1997; Braunschweig et al., 2000) have suggested that the effects of an individual locus are confounded in statistical analyses, even when they are included simultaneously in the model, because certain alleles at the casein loci may appear together more or less frequently than expected with a random combination. However, their influence on milk traits could be due to the cumulative effects of different casein loci on chromosome 6. Consequently, the effects of casein genotypes should be estimated using the whole casein cluster instead of single casein loci (Boettcher et al., 2004; Gambacorta et al., 2005; Secchiari et al., 2009; Perna et al., 2013).

Fat is the major substance defining the energetic value of milk and it makes a major contribution to the nutritional properties of milk. Lipids in milk are mainly present as an oil-in-water emulsion in the form of globules with a diameter that ranges between $<0.1$ and approximately $18 \mu \mathrm{m}$, with an average diameter of about $4 \mu \mathrm{m}$ in cow milk (El-Zeini, 2006; Martini et al., 2013a). The globules consist of a triglyceride core surrounded by a natural biological membrane composed mainly of cholesterol, enzymes, glycoproteins, and glycolipids (Fauquant et al., 2007). About $70 \%$ of all fat globules have a diameter of $<4 \mu \mathrm{m}$, whereas $20 \%$ of globules, which represents almost the entire weight of the fat, have diameters between 4 and $6 \mu \mathrm{m}$ (Barłowska et al., 2011). The milk fatty acids and fat globule size influence the physicochemical, nutritional, and sensorial properties of milk and milk products, as well as their technological ability (Michalski et al., 2003; Fauquant et al., 2005). They, in turn, are affected by various factors, both endogenous (breed, individual milk production, state of health, lactation stage) and exogenous (environmental conditions and farm management, with special reference to the type of diet) (Michalski et al., 2005; Couvreur et al., 2006; Janik et al., 2008; Martini et al., 2013b). The influence of milk protein polymorphisms on morphometric characteristics and the fatty acid composition of milk has been detected in sheep (Martini et al., 2006) and goats (Chilliard et al., 2006; Cebo et al., 2012). In the 
bovine, the connection between milk protein polymorphism and fatty acid composition has been thoroughly investigated (Bobe et al., 2004; Melia et al., 2009). However, little information is reported in the literature on the association between milk protein polymorphism and morphometric characteristics of milk fat globules. Martini et al. (2007) detected relationships among fat globule size and $\beta-\mathrm{CN}, \kappa-\mathrm{CN}$, and $\beta-\mathrm{LG}$ polymorphisms in Holstein milk. The aim of our study was to estimate the effects of casein haplotypes on morphometric characteristics and fatty acid composition of milk in Italian Holstein cows.

\section{MATERIALS AND METHODS}

\section{Animals and Sampling}

This study was conducted on an intensive farm, consisting of more than 500 Italian Holstein cattle, in the countryside of Potenza, southern Italy. Before starting the experiment, about 250 animals in lactation were identified by isoelectric focusing (IEF) to define their haplotypes. Haplotypes were formed by combining individual allelic loci of $\alpha_{\mathrm{S1}^{-}}, \beta-$, and $\kappa_{-} \mathrm{CN}$. After defining individual phenotypes, the cows were grouped by haplotype. Each group consisted of 10 to 12 animals, at similar stages of lactation (70 to $120 \mathrm{~d}$ postpartum), season (spring), and parity (third calving). All animals were fed a commercial standard diet according to milk yield. Individual milk samples of cows at the morning milking were collected once and all milk samples were stored at $4^{\circ} \mathrm{C}$ until analysis; determination of fat globule size was conducted on fresh milk samples. Individual milk samples from each cow were analyzed and each analysis was carried out in triplicate.

\section{Sample Preparation for IEF}

Individual milk samples were defatted by centrifugation $\left(3,000 \times g\right.$ for $30 \mathrm{~min}$ at $\left.4^{\circ} \mathrm{C}\right)$; the fat layer was solidified at $-20^{\circ} \mathrm{C}$ for $20 \mathrm{~min}$ and removed. Casein was prepared by isoelectric precipitation at $\mathrm{pH} 4.6$ with $10 \%$ ( $\mathrm{vol} / \mathrm{vol}$ ) acid acetic and $1 M$ sodium acetate at room temperature. After centrifugation at $3,000 \times g$ for 10 min at $4^{\circ} \mathrm{C}$, the casein pellet was washed twice with distilled water and stored at $-20^{\circ} \mathrm{C}$. The whole casein was dissolved in $9 \mathrm{M}$ urea and $1 \%$ 2-mercaptoethanol for IEF analysis, according to Aschaffenburg and Drewry (1959).

\section{Genetic Variants of Casein by IEF}

The genetic variants of the different caseins by IEF were determined according to the method of Trieu-Cuot and Gripon (1981). The IEF analysis was performed on polyacrylamide gel (5\% acrylamide and $0.15 \%$ bisacrylamide) with a thickness of $1 \mathrm{~mm}$ and $2 \%$ carrier ampholytes to create a gradient of $\mathrm{pH} 2.5$ to 10 . The gel was prefocused at a constant value of $0.35 \mathrm{~W} / \mathrm{mL}$ of gel and at the maximum limit of 1,200 V. The gel was stained in Coomassie Brilliant Blue G-250 according to Blakesley and Boezi (1977). Haplotype frequencies were determined by the number of each haplotype divided by the total number of haplotypes $\left[\%=\left(\mathrm{n}_{\mathrm{i}}\right.\right.$, haplotype $/$ $\left.\left.\mathrm{n}_{\text {total, haplotype }}\right) \times 100\right]$. Haplotypes are presented in order for $\alpha_{\mathrm{S1}^{-}}, \beta-$, and $\kappa-\mathrm{CN}$, respectively.

\section{Determination of Fat Globule Size}

Milk fat globule size were determined as described by Martini et al. (2013b). Image acquisition and processing $(100 \times)$ were performed using a fluorescence microscope (Axioskop, Zeiss, Germany) equipped with Image J software (National Institutes for Health, Bethesda, MD). After determination of diameter, fat globules were divided into 3 size classes: small globules (diameter $<2 \mu \mathrm{m}$ ), medium-sized globules (diameter from 2 to $5 \mu \mathrm{m}$ ), and large globules (diameter $>5 \mu \mathrm{m}$ ). In addition, the percentage incidence of each globule class on total measured milk fat globules was calculated separately for haplotype: $\Sigma n_{\text {i globules (each class) }} / \Sigma n_{\text {total globules }}$ $\times 100$.

\section{Determination of Fatty Acid Profile}

Total lipids of the samples were extracted using chloroform/methanol (2:1, vol/vol) according to Folch et al. (1957), and FAME were prepared according to the ISO (1978) method. Analysis was performed using a Varian 3400 gas chromatograph (Varian, Turin, Italy), equipped with a split-splitless injector, an Omegawax 250 capillary column $(30 \mathrm{~m} \times 0.25 \mu \mathrm{m}$ i.d. $\times 0.25 \mu \mathrm{m}$ film thickness; Thermo Fisher Scientific, Milan, Italy), and a flame-ionization detector. Helium was used as carrier gas at a flow rate of $1.0 \mathrm{~mL} / \mathrm{min}$, and the injector and detector temperatures were set at $250^{\circ} \mathrm{C}$ and $220^{\circ} \mathrm{C}$, respectively. The oven temperature program was $50^{\circ} \mathrm{C}$ for $2 \mathrm{~min}$, increasing at $4^{\circ} \mathrm{C} / \mathrm{min}$ up to $220^{\circ} \mathrm{C}$, where it was maintained for $15 \mathrm{~min}$.

Individual FAME were identified by comparing their retention times with those of the corresponding pure standards (Sigma-Aldrich, Milan, Italy). Quantitative analysis was obtained by peak area integration using the Galaxie Chromatography Data System version 1.9.3.2 software (Varian), and results were expressed as percentage of the total fatty acids analyzed. To evaluate the nutritional implications, PUFA:SFA and n-6:n-3 ratios, and atherogenic and thrombogenic indices were 
calculated. The atherogenic and thrombogenic indices were calculated using the Ulbricht and Southgate (1991) equations:

$$
\begin{aligned}
& \text { Atherogenic index }=[(4 \times \mathrm{C} 14: 0)+\mathrm{C} 16: 0] /
\end{aligned}
$$

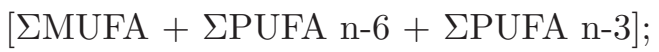

$$
\begin{aligned}
& \text { Thrombogenic index }=(\mathrm{C} 14: 0+\mathrm{C} 16: 0+\mathrm{C} 18: 0) / \\
& (0.5 \text { MUFA + 0.5 PUFA n- } 6+3 \text { PUFA n-3 } \\
& + \text { PUFAn-3/PUFAn-6). }
\end{aligned}
$$

\section{Statistical Analysis}

Data were analyzed according to the following linear model (SAS Institute, 1996):

$$
\mathrm{y}_{i k}=\mu+\alpha_{i}+\varepsilon_{i k},
$$

where $\mathrm{y}_{i k}$ is the observation; $\mu$ is the overall mean; $\alpha_{i}$ is the fixed effect of the $i$ th haplotype $(i=1,2,3$, $4,5)$; and $\varepsilon_{i k}$ is the random error. Before setting the values (expressed as percentages), they were subjected to angular transformation. Student's $t$-test was used to compare all variables. Differences between means at the $95 \%(P<0.05)$ confidence level were considered statistically significant.

\section{RESULTS AND DISCUSSION}

\section{Haplotype Frequencies}

In the study population, 5 different casein haplotypes were identified by IEF. The different allelic combinations of loci $\alpha_{\mathrm{S}_{1}^{-}}, \beta-$, and $\kappa-\mathrm{CN}$ and their frequencies are reported in Table 1 . Haplotypes $B B-A^{2} A^{1}-A A, B B$ $A^{2} A^{2}-A A$, and $B B-A^{2} A^{2}-A B$ had the highest frequency $(>28 \%)$, followed by $B B-A^{2} A^{2}-B B(7.89 \%) ; B B-A^{1} A^{1}$ $A A$ had the lowest frequency $(<5 \%)$. Likely, the selection boost carried out for specific aspects only (e.g., fat and protein yields) decreased the variability of allelic combinations.

Table 1. Frequencies of the $\alpha_{S 1}-\mathrm{CN}, \beta-\mathrm{CN}$, and $\kappa$-CN haplotypes in Italian Holstein milk

\begin{tabular}{lc}
\hline $\begin{array}{l}\text { Haplotype } \\
\left(\alpha_{\mathrm{S} 1}-\mathrm{CN}, \beta-\mathrm{CN}, \kappa-\mathrm{KN}\right)\end{array}$ & $\begin{array}{c}\text { Frequency } \\
(\%)\end{array}$ \\
\hline$B B-A^{2} A^{1}-A A$ & 30.13 \\
$B B-A^{2} A^{2}-A A$ & 29.09 \\
$B B-A^{2} A^{2}-A B$ & 28.41 \\
$B B-A^{2} A^{2}-B B$ & 7.89 \\
$B B-A^{1} A^{1}-A A$ & 4.47 \\
\hline
\end{tabular}

\section{Effect of Casein Haplotype on Fat Globule Size}

Fat globule size, clustered according to the 3 classes analyzed, is reported in Table 2. Overall, the studied milk samples showed an overall mean fat globule diameter of $3.85 \mu \mathrm{m}$, with a mean value of $1.63 \mu \mathrm{m}$ for small globules, $3.45 \mu \mathrm{m}$ for medium globules, and 5.90 $\mu \mathrm{m}$ for large globules. These findings are in agreement with that by other authors (Czerniewicz et al., 2006; Martini et al., 2013a). Casein haplotype significantly affected fat globule size $(P<0.01)$. This is consistent with Ollier et al. (2008), who observed in goat milk that polymorphisms in $\alpha_{S_{1}}$ CN influenced expression of key lipogenic genes that regulate membrane fluidity, cell-cell interactions, and chromatin organization. Significant differences in average diameter were observed among the studied haplotypes. In particular, the $B B-A^{2} A^{1}-A A$ haplotype gave milk with a significantly higher fat globule diameter $(P<0.05)$, whereas $B B$ $A^{2} A^{2}-A B$ and $B B-A^{2} A^{2}-B B$ milk had the lowest fat globule diameters. Within the small fat globule class, $B B-A^{1} A^{1}-A A$ milk had the lowest fat globule diameter $(1.55 \mu \mathrm{m} ; P<0.05)$, whereas small fat globules were not detected in $B B-A^{2} A^{1}-A A$ milk. Cebo et al.(2012), in goat milk, observed that the genetic polymorphism at the $\alpha_{S_{1}-} \mathrm{CN}$ locus is related to milk fat globules, including size and $\zeta$-potential, together with the lipid and protein composition of the milk fat globule membrane. It is known that small droplets of triacylglycerol are synthesized in or on the surfaces of rough endoplasmic reticulum membranes and released into the cytoplasm as microlipid droplets with a surface coat of protein and polar lipid (Mather and Keenan, 1998). Some lipid droplets grow substantially between the time of their formation and the time of their secretion (Scow et al., 1980). Furthermore, post-secretion, some of the larger milk fat globules may fuse with smaller ones and thereby increase their diameter (Argov et al., 2008). In light of this, we hypothesized that, in our study, the formation of large globules and rare presence or absence of small globules could be due to the biochemical balances associated with the haplotype, which influences the surface charge of the milk fat globule membrane, and thus would lead to a more rapid aggregation of the fat droplets. Furthermore, fatty acids associated with phospholipids may affect membrane fluidity and, hence, the likelihood of globules to coalesce into larger globules (Bitman and Wood, 1990). For the medium and large globule classes, $B B-A^{2} A^{2}-B B$ milk had globules at the lower end of the range for medium globules $(3.19 \mu \mathrm{m} ; P$ $<0.05$ ), whereas $B B-A^{1} A^{1}-A A$ and $B B-A^{2} A^{1}-A A$ milks had globules at the highest diameters of large globules (6.03 and $6.08 \mu \mathrm{m}$, respectively; $P<0.05$ ). 


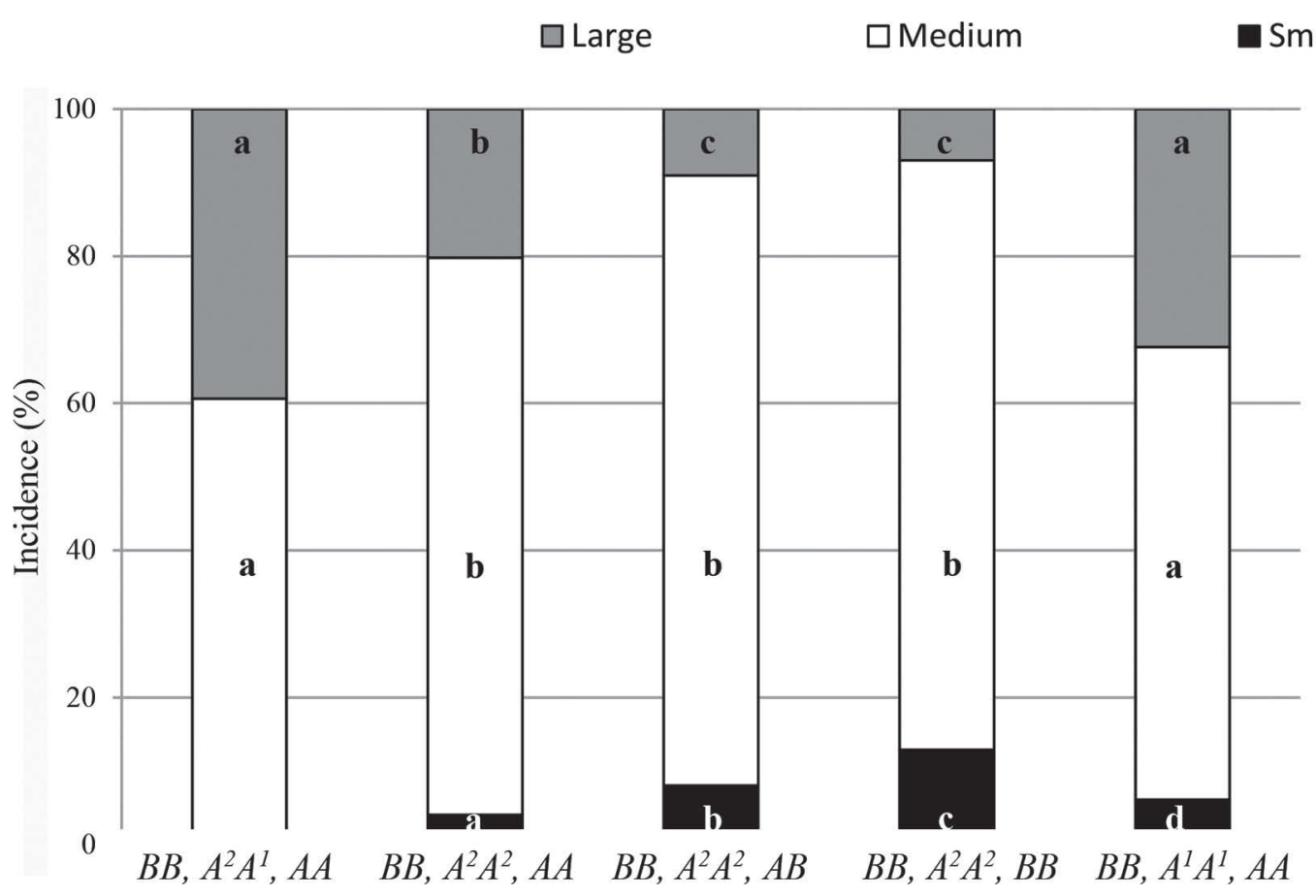

Figure 1. Percentage incidence of each globule class (large, medium, and small) on total measured milk fat globules separately for each casein haplotype (shown in order: $\left.\alpha_{S_{1}}-\mathrm{CN}, \beta-\mathrm{CN}, \kappa-\mathrm{CN}\right)$. Significant differences $(P<0.05)$ within each globule class are indicated by different letters $(\mathrm{a}-\mathrm{d})$.

In addition, we calculated the percentage incidence of each globule class on total measured milk fat globules separately by haplotype (Figure 1). Within the small fat globule class, for $\alpha_{\mathrm{S} 1}-\mathrm{CN}$ variant $B B$ and $\beta-\mathrm{CN}$ variant $A^{2} A^{2}, B B-A^{2} A^{2}-B B$ milk had the highest percentage $(12.7 \% ; P<0.05)$ and $B B-A^{2} A^{2}-A A$ milk had the lowest percentage $(4.2 \% ; P<0.05)$. These findings are supported by Martini et al. (2007), who reported that, in Italian Holstein milk, the $B B$ genotype of $\kappa-\mathrm{CN}$ showed a higher percentage of smaller globules than did the $A B$ and $A A$ genotypes. Milk with haplotypes $B B-A^{2} A^{2}-A B, B B-A^{2} A^{2}-B B$, and $B B-A^{2} A^{2}-A A$ had the highest percentages of medium-sized globules (83.0, 80.4 , and $75.4 \%$, respectively; $P<0.05$ ) compared with the other studied haplotypes. Within the large fat globules class, $B B-A^{2} A^{1}-A A$ and $B B-A^{1} A^{1}-A A$ milks had the highest percentages of large fat globules (39.5 and $32.0 \%$, respectively; $P<0.05$ ).

\section{Effect of Casein Haplotype on Fatty Acid Composition}

The fatty acid profiles of milk from the 5 studied haplotypes are reported in Table 3. Casein haplotype

Table 2. Fat globules diameter $(\mu \mathrm{m})$ of Italian Holstein milk separately for casein haplotype

\begin{tabular}{|c|c|c|c|c|c|c|c|c|}
\hline \multirow{3}{*}{$\begin{array}{l}\text { Haplotype } \\
\left(\alpha_{\mathrm{S1}^{-}} \mathrm{CN}, \beta-\mathrm{CN}, \kappa-\mathrm{CN}\right)\end{array}$} & \multicolumn{8}{|c|}{ Globule } \\
\hline & \multicolumn{2}{|c|}{$\begin{array}{l}\text { Small } \\
(<2 \mu \mathrm{m})\end{array}$} & \multicolumn{2}{|c|}{$\begin{array}{c}\text { Medium } \\
(>2 \leq 5 \mu \mathrm{m})\end{array}$} & \multicolumn{2}{|c|}{$\begin{array}{l}\text { Large } \\
(>5 \mu \mathrm{m})\end{array}$} & \multicolumn{2}{|c|}{ Overall } \\
\hline & Mean & $\mathrm{SD}$ & Mean & $\mathrm{SD}$ & Mean & $\mathrm{SD}$ & Mean & $\mathrm{SD}$ \\
\hline$B B-A^{2} A^{1}-A A$ & $\mathrm{ND}^{1}$ & ND & $3.64^{\mathrm{a}}$ & 0.19 & $6.08^{\mathrm{a}}$ & 0.11 & $4.86^{\mathrm{a}}$ & 0.36 \\
\hline$B B-A^{2} A^{2}-A A$ & $1.69^{\mathrm{a}}$ & 0.04 & $3.63^{\mathrm{a}}$ & 0.04 & $5.84^{\mathrm{b}}$ & 0.15 & $3.70^{\mathrm{b}}$ & 0.16 \\
\hline$B B-A^{1} A^{1}-A A$ & $1.55^{\mathrm{c}}$ & 0.04 & $3.47^{\mathrm{a}}$ & 0.36 & $6.03^{\mathrm{a}}$ & 0.12 & $3.68^{\mathrm{bd}}$ & 0.17 \\
\hline
\end{tabular}

\footnotetext{
${ }^{\mathrm{a}-\mathrm{d}}$ Means within a column with different superscripts differ $(P<0.05)$.

${ }^{1}$ Not detected.
} 
significantly affected the fatty acid composition of milk $(P<0.01)$. This result is in line with that reported by many authors (Bobe et al., 2004; Ferlay et al., 2008), even though those authors considered single casein loci, not the whole casein cluster. In this study, despite significant differences in some individual SFA, we found no significant effect for total SFA content. In particular, the content of $\mathrm{C} 4: 0$ was lower in $B B$ $A^{2} A^{2}-B B$ and $B B-A^{1} A^{1}-A A$ milk compared with milks of other haplotypes (2.84 and $2.54 \%$, respectively; $P<$ 0.05). Several studies have highlighted the role of $\mathrm{C} 4: 0$ fatty acid on human health; in fact, C4:0 regulates fluid transport, protects colonocytes from oxidative stress, and modulates cell proliferation and differentiation; it is also important for its alleged antitumor activity (Parodi, 1999; Canani et al., 2011; Załęski et al., 2013). In the current study, the $B B-A^{2} A^{2}-A B, B B$ $A^{2} A^{2}-B B$, and $B B-A^{2} A^{1}-A A$ milks showed the highest contents of saturated short-chain fatty acids (C6:0, C8:0, and C10:0). These fatty acids are particularly digestible, have a low tendency for adipose formation, and (together with C18:0) do not affect serum cholesterol levels (Fushimi et al., 2006; Marten et al., 2006). Furthermore, Neyts et al. (2000) reported that C4:0, C6:0, C8:0, and C10:0 fatty acids exert antimicrobial and antiviral activities in both in vitro and in vivo animal studies. The $B B-A^{2} A^{1}-A A$ milk showed the highest contents of $\mathrm{C} 12: 0(6.11 \% ; P<0.05)$ and $\mathrm{C} 14: 0(14.19 \%$; $P<0.05)$, whereas milk with haplotype $B B-A^{2} A^{2}-A A$ showed the highest $\mathrm{C} 16: 0$ content $(22.43 \% ; P<0.05)$. From a general nutritional point of view, C12:0, C14:0, and C16:0 acids, synthesized de novo in the mammary gland, have a hypercholesterolemic effect because they are associated with a higher concentration of lowdensity lipoprotein (LDL; Mensink et al., 2003). Other authors (Bobe et al., 2004; Melia et al., 2009) reported that allele $C S N 3 \mathrm{~B}$ is associated with increased de novo fatty acid synthesis in the mammary gland. In particular, C14:0 acid is the most atherogenic fatty acid, having 4 times the cholesterol-raising potential of C16:0 (Ulbricht, 1995). With regard to $\mathrm{C} 18: 0, B B-A^{2} A^{2}-A A$ and $B B-A^{2} A^{1}-A A$ milks showed the lowest content (9.41 and $10.06 \%$, respectively; $P<0.05$ ). This fatty acid has been shown to have no net effect on plasma levels of either LDL or high-density lipoprotein (HDL) cholesterol in humans (Bonanome and Grundy, 1988; Yu et al., 1995) and is not atherogenic (Mensink et al., 2003). This effect of C18:0 acid has been attributed to its reduced digestibility and easy desaturation into oleic acid (C18:1; Bonanome and Grundy, 1988). Oleic acid is the most prevalent MUFA in milk from ruminants. In the current study, $B B-A^{2} A^{2}-A B$ milk showed the highest content of C18:1n-9 (18.40\%, $P<0.05)$, whereas $B B-A^{2} A^{2}-B B$ milk showed the lowest content of C18:1n-9 (16.19\%). From a nutritional viewpoint, C18:1n-9 has a hypocholesterolemic effect because it positively modifies the LDL:HDL ratio (Ulbricht and Southgate, 1991). Melia et al. (2009) reported that allele $C S N 3 \mathrm{~B}$ is negatively associated with $\mathrm{C} 18: 1 \mathrm{n}-9$ content. The $B B-A^{2} A^{2}-A A$ and $B B-A^{2} A^{1}-A A$ milks showed the lowest percentage of $\mathrm{C} 18: 2 \mathrm{n}-6$ (3.13 and $2.81 \%$, respectively; $P<0.05$ ), and consequently of n-6 PUFA, whereas C18:3n-3 content was significantly lower in $B B-A^{2} A^{2}-A B$ and $B B-A^{2} A^{1}-A A$ milk (0.66 and $0.65 \%$, respectively; $P<0.05)$. The $B B-A^{2} A^{2}-A A$ and $B B-A^{2} A^{1}-A A$ milks had the lowest C20:5n-3 (eicosapentaenoic acid) content $(P<0.05)$, whereas $B B-A^{2} A^{2}-A A$ milk had the lowest $\mathrm{C} 22: 6 \mathrm{n}-3$ (docosahexaenoic acid) content. The C18:2n-6 (cis) fatty acid is the precursor of C20:4n-6, which is considered advantageous for cardiovascular health only when present in low amounts, being antagonist of the health benefits resulting from the n-3 fatty acids (Parra et al., 2007). The n-3 PUFA, such as C18:3n-3 and docosahexaenoic acid, instead, are regulators of gene expression in the body (Kaur et al., 2011). In particular, C18:3n-3 may have an antiadipogenenic action because of competition with C18:2n-6 in the synthesis of C20:4n-6 (Kaur et al., 2011). In general, the mean content of CLA in milk was $0.56 \%$, in agreement with the amount detected by Secchiari et al. (2002). In particular, $B B-A^{1} A^{1}-A A$ milk showed the highest percentage of CLA $(0.68 \% ; P<$ $0.05)$, whereas $B B-A^{2} A^{2}-A B$ milk presented the lowest content $(0.44 \%)$. The CLA have important biological activities, including anticarcinogenic and hypocholesterolemic properties (Jenkins et al., 2006).

Nutritional indices and ratios of the lipid fraction of milk with different casein haplotypes are reported in Table 4. Statistical analysis showed a significant effect of casein haplotype on nutritional indices and ratio $(P<0.01)$. The ratio of PUFA to SFA found in our samples was below the nutrition recommendations proposed by the UK Department of Health (1994); in particular, $B B-A^{2} A^{1}-A A$ milk showed the lowest value $(0.064 ; P<0.05)$ compared with the other studied haplotypes. In fact, the UK Department of Health (1994) recommended a PUFA:SFA ratio $>0.40$ to prevent excesses of some SFA that have a negative effect on the LDL cholesterol plasma level, and of some PUFA that are precursors of powerful clotting agents and that are involved in the etiology of some cancers. Currently, the European Food Safety Authority (EFSA), has not set specific values for PUFA:SFA but, among its recommendations, proposes a general reduction in the intake of SFA and an increase in the intake of n-3 PUFA (EFSA, 2010). However, the PUFA to SFA ratio may not be completely suitable to evaluate the nutritional value of fat because it ignores the effect of MUFA, 
such as C18:1n-9 (cis), and overestimates the effect of some SFA, such as C18:0, that do not increase plasma cholesterol (Santos-Silva et al., 2002). Therefore, it is necessary to use other nutritional indices and ratios, suc as n-6:n-3 ratio, atherogenic index, and thrombogenic index, which best define the dietetic properties of milk fat. Our samples showed a mean n-6:n-3 ratio of 3.56 ; in particular, $B B-A^{2} A^{1}-A A$ milk showed the best value $(3.19 ; P<0.05)$. EFSA (2010) proposed not to set specific values for n- 3 and n- 6 intakes, because biochemical and clinical data in human are insufficient to recommend a value independent of absolute levels of intake. However, Simopoulos (1999) recommended a low intake of n- 6 PUFA to avoid the prothrombotic and proaggregatory effects. In this study, $B B-A^{2} A^{1}-A A$ milk showed the highest atherogenic index $(P<0.05)$ and thrombogenic values, whereas $B B-A^{2} A^{2}-A B$ milk showed the lowest values.

Table 3. Fatty acid composition (\%) of the Italian Holstein milk separately for casein haplotype

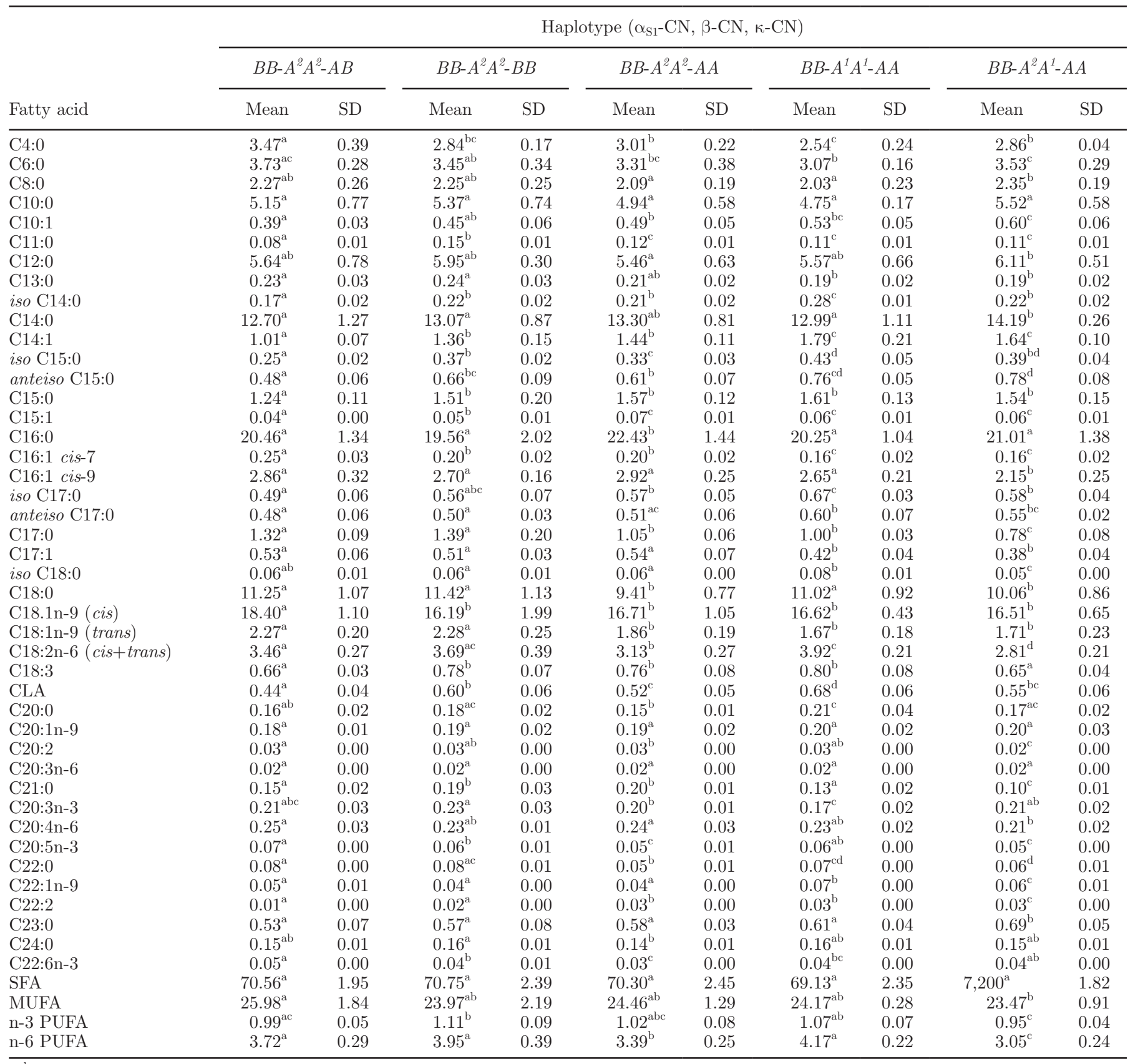

\footnotetext{
${ }^{\mathrm{a}-\mathrm{d}}$ Means within a row with different superscripts differ $(P<0.05)$.
} 
Table 4. Fatty acid ratios and nutritional indices of Holstein milk, separately for casein haplotype

Haplotype $\left(\alpha_{\mathrm{S} 1}-\mathrm{CN}, \beta-\mathrm{CN}, \kappa-\mathrm{CN}\right)$

\begin{tabular}{|c|c|c|c|c|c|c|c|c|c|c|}
\hline \multirow{2}{*}{ Ratio or index ${ }^{1}$} & \multirow{2}{*}{\multicolumn{2}{|c|}{$B B-A^{2} A^{2}-A B$}} & \multirow{2}{*}{\multicolumn{2}{|c|}{$B B-A^{2} A^{2}-B B$}} & \multirow{2}{*}{\multicolumn{2}{|c|}{$B B-A^{2} A^{2}-A A$}} & & & & \\
\hline & & & & & & & \multicolumn{2}{|c|}{$B B-A^{1} A^{1}-A A$} & \multicolumn{2}{|c|}{$B B-A^{2} A^{1}-A A$} \\
\hline PUFA:SFA & $0.07^{\mathrm{ab}}$ & 0.01 & $0.08^{\mathrm{ac}}$ & 0.01 & $0.07^{\mathrm{b}}$ & 0.01 & $0.09^{\mathrm{c}}$ & 0.01 & $0.06^{\mathrm{d}}$ & 0.01 \\
\hline n-6:n-3 & $3.77^{\mathrm{a}}$ & 0.31 & $3.58^{\mathrm{ab}}$ & 0.39 & $3.35^{\mathrm{bc}}$ & 0.29 & $3.90^{\mathrm{a}}$ & 0.03 & $3.19^{\mathrm{c}}$ & 0.21 \\
\hline Atherogenic index & $2.51^{\mathrm{a}}$ & 0.26 & $2.70^{\mathrm{ab}}$ & 0.33 & $2.82^{\mathrm{b}}$ & 0.27 & $2.65^{\mathrm{b}}$ & 0.26 & $3.06^{\mathrm{c}}$ & 0.18 \\
\hline Thrombogenic index & $2.46^{\mathrm{a}}$ & 0.11 & $2.52^{\mathrm{ab}}$ & 0.25 & $2.62^{\mathrm{ab}}$ & 0.20 & $2.51^{\mathrm{ab}}$ & 0.12 & $2.76^{\mathrm{b}}$ & 0.21 \\
\hline
\end{tabular}

${ }^{\mathrm{a}-\mathrm{d}}$ Means within a row with different superscripts differ $(P<0.05)$.

${ }^{1}$ Atherogenic index $=[(4 \times \mathrm{C} 14: 0)+\mathrm{C} 16: 0] /[$ MUFA + EPUFA n-6 + EPUFA n-3]; thrombogenic index $=(\mathrm{C} 14: 0+\mathrm{C} 16: 0+\mathrm{C} 18: 0) /(0.5$ MUFA + 0.5 PUFA n-6 + 3 PUFA n-3 + PUFAn-3/PUFAn-6).

\section{CONCLUSIONS}

The morphometric characteristics and fatty acid composition of milk are strongly influenced by casein polymorphism, as shown by the significant differences found among casein haplotypes of milk. These results are of interest because the degree of differentiation in globule size influences the renneting, cheese texture, color, flavor, and butter texture. Therefore, although more studies are needed to confirm these findings, our work suggests that, a separate analysis of milk for haplotype could be useful to obtain milk characterized by different sizes of milk globules, in order to allocate milk toward a more productive trade, for both fresh consumption and manufacture of dairy products.

\section{REFERENCES}

Argov, N., D. G. Lemay, and J. B. German. 2008. Milk fat globule structure and function: nanoscience comes to milk production. Trends Food Sci. Technol. 19:617-623.

Aschaffenburg, R., and J. Drewry. 1959. New procedure for the routine determination of the various non-casein proteins of milk. Proc. 15th Int. Dairy Congr. London, UK. 3:1631-1637. Richard Clay and Co., Bungay, Suffolk, UK.

Barłowska, J., M. Szwajkowska, Z. Litwińczuk, and J. Król. 2011. Nutritional value and technological suitability of milk from various animal species used for dairy production. Compr. Rev. Food Sci. Food Safety 10:291-302.

Bitman, J., and D. L. Wood. 1990. Changes in milk fat phospholipids during lactation. J. Dairy Sci. 73:1208-1216.

Blakesley, R. W., and J. A. Boezi. 1977. A new staining technique for proteins in polyacrylamide gels using Coomassie Brilliant Blue G250. Anal. Biochem. 82:580-582.

Bobe, G., A. E. Freeman, G. L. Lindberg, and D. C. Beitz. 2004. The influence of milk protein phenotypes on fatty acid composition of milk from Holstein cows. Milchwissenschaft 59:3-6.

Boettcher, P. J., A. Caroli, A. Stella, S. Chessa, E. Budelli, F. Canavesi, S. Ghiroldi, and G. Pagnacco. 2004. Effects of casein haplotype on milk production traits in Italian Holstein and Brown Swiss cattle. J. Dairy Sci. 87:4311-4317.

Bonanome, A., and S. M. Grundy. 1988. Effect of dietary stearic acid on plasma cholesterol and lipoprotein levels. N. Engl. J. Med. 318:1244-1248.

Braunschweig, M., C. Hagger, G. Stranzinger, and Z. Puhan. 2000. Association between casein haplotype and milk production traits of Swiss cattle. J. Dairy Sci. 83:1387-1395.
Canani, R. B., M. D. Costanzo, L. Leone, M. Pedata, R. Meli, and A. Calignano. 2011. Potential beneficial effects of butyrate in intestinal and extraintestinal diseases. World J. Gastroenterol. 17:15191528.

Caroli, A. M., S. Chessa, and G. J. Erhardt. 2009. Invited review: Milk protein polymorphisms in cattle: Effect on animal breeding and human nutrition. J. Dairy Sci. 92:5335-5352.

Cebo, C., C. Lopez, C. Henry, C. Beauvallet, O. Ménard, C. Bevilacqua, F. Bouvier, H. Caillat, and P. Martin. 2012. Goat $\alpha_{\mathrm{s} 1}$-casein genotype affects milk fat globule physicochemical properties and the composition of the milk fat globule membrane. J. Dairy Sci. 95:6215-6229.

Chilliard, Y., J. Rouel, and C. Leroux. 2006. Goat's alpha-S1 casein genotype influences its milk fatty acid composition and delta-9 desaturation ratios. Anim. Feed Sci. Technol. 131:474-487.

Couvreur, S., C. Hurtaud, C. Lopez, L. Delaby, and J. L. Peyraud. 2006. The linear relationship between the proportion of fresh grass in the cow diet, milk fatty acid composition, and butter properties. J. Dairy Sci. 89:1956-1969.

Czerniewicz, M., K. Kielczewska, and A. Kruk. 2006. Comparison of some physicochemical properties of milk from Holstein-Friesian and Jersey cows. Pol. J. Food Nutr. Sci. 15:17-21.

Di Stasio, L., and P. Mariani. 2000. The role of protein polymorphism in the genetic improvement of milk production. Zootec. Nutr. Anim. 3:69-90

EFSA. 2010. Scientific opinion on dietary reference values for fats, including saturated fatty acids, polyunsaturated fatty acids, monounsaturated fatty acids, trans fatty acids, and cholesterol. EFSA J. 146:1-106.

El-Zeini, H. 2006. Microstructure rheological and geometrical properties of fat globules of milk from different animal species. Pol. J. Food Nutr. Sci. 56:147-154.

Fauquant, C., V. Briad, N. Leconte, and M. C. Michalski. 2005. Differently sized native milk fat globules separated by microfiltration: Fatty acid composition of the milk fat globule membrane and triglyceride core. Eur. J. Lipid Sci. Technol. 107:80-86.

Fauquant, C., V. Briard-Bion, N. Leconte, M. Guichardant, and M. Michalski. 2007. Membrane phospholipids and sterols in microfiltered milk fat globules. Eur. J. Lipid Sci. Technol. 12:1167-1173.

Ferlay, A., C. Agabriel, C. Sibra, C. Journal, B. Martin, and Y. Chilliard. 2008. Tanker milk variability in fatty acids according to farm feeding and husbandry practices in a French semi-mountain area. Dairy Sci. Technol. 88:193-215.

Folch, J., M. Lees, and G. H. Sloane. 1957. A simple method for the isolation and purification of total lipides from animal tissues. J. Biol. Chem. 226:497-509.

Fushimi, T., K. Suruga, Y. Oshima, M. Fukiharu, Y. Tsukamoto, and T. Goda. 2006. Dietary acetic acid reduces serum cholesterol and triacylglycerols in rats fed a cholesterol-rich diet. Br. J. Nutr. 95:916-924.

Gambacorta, E., C. Cosentino, M. Gambacorta, D. Marsico, and A. Perna. 2005. Podolian breed cows: Casein genotype and cheesemaking attitude in pasta filata and in hard pressed curd cheese. 
Pages 153-162 in Proc. 40th Simp. Intern. Zootec. From Genome to Proteome in Animal Science. Istituto Sperimentale Italiano "Lazzaro Spallanzani," Lodi, Italy.

International Organization for Standardization (ISO). 1978. Animal and vegetable fats and oils - Preparation of methyl esters of fatty acids. Method ISO 5509. ISO, Geneva, Switzerland.

Janik, I., B. Martin, and S. A. Chadd. 2008. Milk particulates and animal health: mastitis in dairy cows. Asp. Appl. Asp. Aerobiol. 89:23-31.

Jenkins, T. C., A. A. AbuGhazaleh, S. Freeman, and E. J. Thies. 2006. The production of 10-hydroxystearic acid and 10-ketostearic acids is an alternate of oleic acid transformation by the ruminal microbiota in cattle. J. Nutr. 136:926-931.

Kaur, G., D. C. Smith, D. Barr, M. Garg, and A. J. Sinclair. 2011. Docosapentaenoic acid (22:5n-3): A review of its biological effects. Prog. Lipid Res. 50:28-34.

Marten, B., M. Pfeuffer, and J. Schrezenmeir. 2006. Medium-chain triglycerides. Int. Dairy J. 16:1374-1382.

Martin, P., M. Szymanowska, L. Zwierzchowski, and C. Leroux. 2002. The impact of genetic polymorphisms on the protein composition of ruminant milks. Reprod. Nutr. Dev. 42:433-459.

Martini, M., I. Altomonte, and F. Salari. 2013b. Evaluation of the fatty acid profile from the core and membrane of fat globules in ewe's milk during lactation. Lebenson. Wiss. Technol. 50:253-258.

Martini, M., F. Cecchi, C. Scolozzi, F. Salari, F. Chiatti, S. Chessa, and A. Caroli. 2007. The influence of milk protein polymorphisms on morphometric characteristics of milk fat globules in Italian Friesian dairy cow. Page 73 in 58th Annu. Mtg. EAAP, Dublin, Ireland. Wageningen Academic Publishers, Wageningen, the Netherlands.

Martini, M., F. Salari, and I. Altomonte. 2013a. The macrostructure of milk lipids: The fat globules. Crit. Rev. Food Sci. Nutr. http:// dx.doi.org/10.1080/10408398.2012.758626.

Martini, M., F. Salari, C. Scolozzi, F. Cecchi, G. Ceriotti, and A. Caroli. 2006. Relationship between milk genetic polymorphism and physico-chemical and nutritional quality of sheep milk. In 14th Int. Congr. Federazione Mediterranea Sanità e Produzione dei Ruminanti (Fe.Me.S.P.Rum.), Lugo, Santiago de Compostela, Spain.

Mather, I. H., and T. W. Keenan. 1998. Origin and secretion of milk lipids. J. Mammary Gland Biol. Neoplasia 3:259-273.

Melia, S., G. Losi, and G. B. Castagnetti. 2009. The influence of milk $\kappa$-casein and $\beta$-lactoglobulin phenotypes on fatty acid composition of milk from Reggiana cows. Dairy Sci. Technol. 89:115-122.

Mensink, R. P., P. L. Zock, A. D. Kester, and M. B. Katan. 2003. Effects of dietary fatty acids and carbohydrates on the ratio of serum total to HDL 148 cholesterol and on serum lipids and apolipoproteins: A meta-analysis of 60 controlled trials. Am. J. Clin. Nutr. 77:1146-1155.

Michalski, M. C., V. Briard, F. Michel, F. Tasson, and P. Poulain. 2005. Size distribution of fat globules in human colostrums, breast milk and infant formula. J. Dairy Sci. 88:1927-1940.

Michalski, M. C., J. Y. Gassi, M. H. Famelart, N. Leconte, B. Camier, F. Michel, and V. Briard. 2003. The size of native milk fat globules affects physico-chemical and sensory properties of Camembert cheese. Lait 83:131-143.
Neyts, K., G. Huy, M. Uyttendaele, J. Swings, and J. Debevere. 2000. Incidence and identification of mesophilic Aeromonas spp. from retail foods. Lett. Appl. Microbiol. 31:359-363.

Ojala, M., T. R. Famula, and J. F. Medrano. 1997. Effect of milk protein genotypes on the variation for milk production traits of Holstein and Jersey cows in California. J. Dairy Sci. 80:1776-1785.

Ollier, S., S. Chauvet, P. Martin, Y. Chilliard, and C. Leroux. 2008. Goat's $\alpha_{\mathrm{S}_{1}}$-casein polymorphism affects gene expression profile of lactating mammary gland. Animal 2:566-573.

Parodi, P. W. 1999. Conjugated linoleic acid and other anticarcinogenic agents of bovine milk fat. J. Dairy Sci. 82:1339-1349.

Parra, D., N. Bandarra, M. Kiely, I. Thorsdottir, and J. Martinez. 2007. Impact of fish intake on oxidative stress when included into a moderate energy-restricted program to treat obesity. Eur. J. Nutr. 46:460-467.

Perna, A., I. Intaglietta, A. Simonetti, and E. Gambacorta. 2013. Effect of genetic type and casein haplotype on antioxidant activity of yogurts during storage. J. Dairy Sci. 96:3435-3441.

Santos-Silva, J., R. J. B. Bessa, and F. Santos-Silva. 2002. Effect of genotype, feeding system and slaughter weight on the quality of light lambs: II. Fatty acid composition of meat. Livest. Sci. 77:187194.

SAS Institute. 1996. SAS User's Guide: Statistics. Version 7. SAS Inst. Inc., Cary, NC.

Scow, R. O., E. J. Blanchette-Mackie, and L. C. Smith. 1980. Transport of lipid across capillary endothelium. Fed. Proc. 39:2610-2617.

Secchiari, P., P. Carnier, A. Priolo, and M. Mele. 2009. Genetic and physiology basis of the quality of livestock products. Ital. J. Agron. 1:81-102.

Secchiari, P., M. Mele, A. Serra, and F. Paoletti. 2002. Le frazioni lipidiche del latte e della carne dei ruminanti. Pages 7-96 in Atti Conv. "Giornata di studio su: Latte e carne dei ruminanti componente lipidica e salute umana". Atti Accademia dei Georgofili, Firenze, Italy.

Simopoulos, A. P. 1999. Essential fatty acids in health and chronic disease. Am. J. Clin. Nutr. 70:560S-569S.

Trieu-Cuot, P., and J. C. Gripon. 1981. Electrofocusing and two-dimensional electrophoresis of bovine caseins. J. Dairy Res. 48:303310

UK Department of Health. 1994. Nutritional aspects of cardiovascular disease: Report of the cardiovascular review group. Committee on Medical Aspects of Food Policy. Department of Health, London, UK.

Ulbricht, T. L. V. 1995. Fat in the food chain. Report to the Ministry of Agriculture Fisheries and Food, London, UK.

Ulbricht, T. L. V., and D. A. T. Southgate. 1991. Coronary heart disease: Seven dietary factors. Lancet 338:985-992.

Yu, S., J. Derr, T. D. Etherton, and P. M. Kris-Etherton. 1995. Plasma cholesterol-predictive equations demonstrate that stearic acid is neutral and monosaturated fatty acids are hypocholesterolemic. Am. J. Clin. Nutr. 61:1129-1139.

Załęski, A., A. Banaszkiewicz, and J. Walkowiak. 2013. Butyric acid in irritable bowel syndrome. Prz. Gastroenterol. 8:350-353. 